\title{
Removing Cationic Dye from Aqueous Solutions Using as-grown and Modified Multi-Walled Carbon Nanotubes
}

\author{
Wojciech Konicki ${ }^{1 *}$, Iwona Pełech ${ }^{2}$ \\ ${ }^{1}$ Department of Environmental Protection, Maritime University of Szczecin, Szczecin, Poland \\ ${ }^{2}$ Institute of Chemical and Environment Engineering, West Pomeranian University of Technology, \\ Szczecin, Poland
}

Received: 12 October 2017

Accepted: 5 February 2018

\begin{abstract}
In this research we studied the adsorption process of Basic Red 46 (BR46) cationic dye onto as-grown (MWCNTs) and modified multi-walled carbon nanotubes (MWCNTs-MOD). MWCNTs were synthesized by the chemical vapor deposition method using ethylene as a carbon source and nanocrystalline iron as catalyst, and oxidized by concentrated nitric acid to give MWCNTs-MOD. The adsorbents were characterized by XRD, TGA, HRTEM, FTIR, BET, and zeta potential measurements. The effects of initial dye concentration (5 to $\left.40 \mathrm{mg} \mathrm{L}^{-1}\right), \mathrm{pH}(4.0$ to 11.5$)$, and temperature $\left(20,40\right.$, and $60^{\circ} \mathrm{C}$ ) on BR46 adsorption onto MWCNTs and MWCNTs-MOD were studied. The isotherm data were analyzed using Langmuir and Freundlich equations. The equilibrium data fit well the Langmuir isotherm for both MWCNTs and MWCNTs-MOD. The maximum adsorption capacities of BR46 onto MWCNTs and MWCNTs-MOD were 19.5 and $51.8 \mathrm{mg} \mathrm{g}^{-1}$, respectively. The pseudo first-order and pseudo second-order kinetic models and the intraparticle diffusion model were used to describe the kinetic data. Kinetic studies showed that the kinetic data were well described by the pseudo second-order kinetic model. The experimental results indicated that the maximum BR46 removal could be attained at a solution $\mathrm{pH}$ of 11.5 and the adsorption capacity obtained was 23.5 and $57.2 \mathrm{mg} \mathrm{g}^{-1}$ for MWCNTs and MWCNTs-MOD, respectively. Thermodynamic parameters $\left(\Delta \mathrm{G}^{\circ}, \Delta \mathrm{H}^{\circ}, \Delta \mathrm{S}^{\circ}\right)$ were obtained and it was found that the adsorption of BR46 onto MWCNTs and MWCNTs-MOD was an endothermic and spontaneous process.
\end{abstract}

Keywords: carbon nanotubes, cationic dye, adsorption, kinetics, thermodynamics

\section{Introduction}

Synthetic dyes are one of the major pollutants found in the effluents of textile, leather, paper, plastic,

*e-mail: w.konicki@am.szczecin.pl food, cosmetics, and other industries. Many dyes are highly toxic, and potentially carcinogenic, mutagenic, teratogenic, and allergenic on exposed organisms. Dyes are extremely stable due to their complex aromatic molecular structure, and are thus difficult to biodegrade. Additionally, their presence in water restricts light penetration, thereby reducing photosynthesis of the 
aqueous flora. Thus, it is imperative to remove dyes from wastewater to an acceptable level before discharging them into the environment. Dyes are broadly classified as anionic, cationic, non-ionic, and zwitterionic, depending on the ionic charge on the dye molecules. Among them, cationic dyes are more toxic than anionic dyes. Cationic dyes can easily interact with negatively charged cell membrane surfaces and can enter into cells and concentrate in the cytoplasma [1]. Therefore, for our studies, we selected as adsorbate cationic dye Basic Red 46 (BR46), which is widely used in dyeing wool, silk, acrylic/cellulosic fiber blends, and polyester. Additionally, BR46 is very toxic to aquatic life with longlasting effects.

Various methods such as coagulation/flocculation [2], biodegradation [3], adsorption [4-6], membrane separation [7], photocatalysis [8-10], and ozonation [11] have been used for removal of synthetic dyes from waters and wastewaters. Among all these methods, adsorption has been found to be one of the most common techniques for dye removal because of its easy operation and effectiveness. As a result, various adsorbents such as activated carbon [12], chitosan [13], carbon nanotubes (CNTs) [14], graphene and graphene oxide [15], zeolites [16], clays [17], cotton [18], orange peel [19], nanocrystalline magnetic composites [20], and fly ash [21] have been investigated for removal of dyes from aqueous solutions. Among the various adsorbents, carbon nanotubes are an attractive alternative for removing organic contaminants such as dyes from water and wastewater, because of their small sizes, large surface areas, unique hollow structures, high mechanical strength, and thermal stability. Qu et al. have synthesized multi-walled carbon nanotubes filled with $\mathrm{Fe}_{2} \mathrm{O}_{3}$ particles for removal of Methylene Blue and Neutral Red from water [22]. Gong et al. have prepared magnetic multiwall carbon nanotube nanocomposite as adsorbent for removal of three cationic dyes: Methylene Blue, Neutral Red, and Brilliant Cresyl Blue from aqueous solutions [23]. Gao et al. have studied the adsorption of anionic azo dyes Orange II, Sunset Yellow FCF, and Amaranth onto magnetic polymer multi-wall carbon nanotube nanocomposite [24]. Kuo et al. have investigated the adsorption of direct dyes Direct Yellow 86 and Direct Red 224 onto carbon nanotubes [25]. Yao et al. have studied the adsorption of Methylene Blue [26] and Methyl Orange [27] from an aqueous solution by multi-walled carbon nanotubes. Wang et al. used multi-walled carbon nanotubes as an adsorbent for removing Methylene Blue and Acid Red 183 from aqueous solution in single and binary dye systems [28].

Surface chemistry of CNTs is critical to their physical and chemical properties and applications. The presence and concentration of surface functional groups play an important role in the adsorption process. Therefore, surface modification of CNTs is performed, because the introduction of various oxygen functional groups can provide new adsorption sites for synthetic dyes. One of the most commonly employed methods of surface modification is the creation of oxygen-containing functional groups by partial oxidation. This aim may be achieved using wet chemical oxidation, usually with aqueous solution of $\mathrm{HNO}_{3}, \mathrm{H}_{2} \mathrm{SO}_{4}$, or their mixtures, oxidation in ozone, oxygen, and oxygen plasma. On the other hand, liquid-phase oxidation is effective in removing both amorphous carbon and metallic catalyst particles remaining in the as-grown CNTs. However, until now little study has been done on adsorption of dyes onto modified CNTs. Ghaedi et al. have investigated the adsorption of Methyl Red [29] and Bromothymol Blue [30] on oxidized multi-walled carbon nanotubes. Mishra et al. have prepared functionalized multi-walled carbon nanotubes by acid treatment $\left(\mathrm{HNO}_{3}\right)$ for removal of Direct Congo Red, Reactive Green HE4BD, and Golden Yellow MR from aqueous solutions [31]. Sheibani et al. have studied the removal of Congo Red from an aqueous solution by multi-walled carbon nanotubes oxidized and treated with $\mathrm{HNO}_{3}$ [32]. Duman et al. have synthesized magnetic oxidized multi-walled carbon nanotubes $\left(\mathrm{HNO}_{3}\right)$ and magnetic oxidized multi-walled carbon nanotubes- $\kappa$-carrageenan and used them as adsorbents for the removal of Methylene Blue from aqueous solution [33].

Hence, our current study was devoted to the adsorption process of the cationic dye Basic Red 46 onto as-grown and modified by a simple oxidation method multi-walled carbon nanotubes. The effects of initial dye concentration, solution $\mathrm{pH}$, and temperature on BR46 adsorption were investigated. The experimental data were analyzed using the pseudo first-order, pseudo second-order, and intraparticle diffusion kinetic models. Langmuir and Freundlich isotherms were employed to quantify the adsorption equilibrium. The thermodynamic parameters of the process, such as enthalpy, entropy, and the Gibbs free energy, were also determined.

\section{Materials and Methods}

\section{Materials}

As-grown multi-walled carbon nanotubes (MWCNTs) were prepared by chemical vapor deposition CVD method using ethylene as a carbon source and nanocrystalline iron as catalyst. Details of the nanocrystalline iron and MWCNTs preparation are given at work [34]. The synthesis of MWCNTs was conducted in a hightemperature furnace (Carbolite STF 16/800) at $700^{\circ} \mathrm{C}$. Afterward, the sample was cooled to room temperature under argon atmosphere.

Surface modification of MWCNTs was performed through oxidation. MWCNTs $(8 \mathrm{~g})$ were oxidized in an aqueous solution of $\mathrm{HNO}_{3}(65 \%, 200 \mathrm{ml})$ at $25^{\circ} \mathrm{C}$ with $24 \mathrm{~h}$ of continuous agitation. After that, the modified MWCNTs (MWCNTs-MOD) were washed with deionized water to neutral $\mathrm{pH}$ and filtered using a polycarbonate membrane (Whatman, $0.2 \mu \mathrm{m}$ pores). Finally, MWCNTs-MOD were dried at $100^{\circ} \mathrm{C}$ for $24 \mathrm{~h}$. 
Cationic dye Basic Red 46 (BR46) $\left(\mathrm{C}_{18} \mathrm{H}_{21} \mathrm{~N}_{6} \mathrm{O}_{4} \mathrm{~S}\right.$, molar mass 417.51) was purchased from Zachem Barwniki. The chemical structure of BR46 is shown in Fig. 1. All solutions were prepared using deionized water.

\section{Characterization Methods}

The phase composition of MWCNTs and MWCNTsMOD was determined using the $\mathrm{x}$-ray diffraction method (X'Pert PRO Philips diffractometer, $\mathrm{CuK} \alpha$ radiation). The amount of iron in both adsorbents was determined using thermogravimetric analysis TGA, which was performed on DTA-Q600 SDT TA Instruments with the heating rate of $10^{\circ} \mathrm{C} \mathrm{min}{ }^{-1}$ from room temperature to $900^{\circ} \mathrm{C}$ in air. The morphology of the adsorbents was investigated by high-resolution transmission electron microscopy HRTEM using a FEI Tecnai F20 operating at $200 \mathrm{kV}$. The BET-specific surface area, total pore volume, and average pore radius of MWCNTs and MWCNTs-MOD were determined from adsorption isotherms using a Quadrasorb SI Quantachrome analyzer. The functional groups onto the surface of both adsorbents were determined using the Fourier transform infrared FTIR method (Nicolet iS5 FT-IR Spectrometric, Thermo Scientific) and recorded in the range of $4000-400 \mathrm{~cm}^{-1}$. Zeta potentials of synthesized materials were determined by a Malvern Instrument Zetasizer 2000 at room temperature. The concentration of BR46 in each aqueous solution was measured on a Genesys 10S UV-Vis spectrophotometer (Thermo Scientific) at $530 \mathrm{~nm}$.

\section{Adsorption Experiments}

Adsorption experiments were carried out in an Erlenmeyer flask, where the dye solution $(200 \mathrm{~mL})$ with initial dye concentration was placed. Initial concentrations of dye varied from 5 to $40 \mathrm{mg} \mathrm{L}^{-1}$. The experiments were conducted individually for MWCNTs and MWCNTs-MOD. The flask with dye solution was sealed and placed in a temperaturecontrolled shaking water bath (Grant OLS26 Aqua Pro, Grant Instruments Ltd.) and agitated at a constant speed of $160 \mathrm{rpm}$. To observe the effect of temperature the experiments were carried out at three different temperatures, i.e., 20,40 , and $60^{\circ} \mathrm{C}$. Before mixing with the adsorbent, various $\mathrm{pH}$ levels of the dye solution

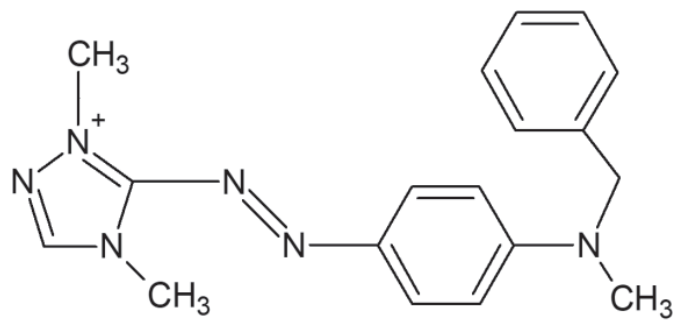

Fig. 1. Chemical structure of BR46. were adjusted by adding a few drops of diluted hydrochloric acid $(0.1 \mathrm{~N} \mathrm{HCl})$ or sodium hydroxide $(0.1 \mathrm{~N} \mathrm{NaOH})$. When the desired temperature was reached, about $40 \mathrm{mg}$ of adsorbent was added into flask. At predetermined moments, $1 \mathrm{ml}$ of aqueous sample was taken from the solution, and the liquid was separated from the adsorbent by centrifugation at $6000 \mathrm{rpm}$ for $5 \mathrm{~min}$. The concentration of BR46 in solution was determined spectrophotometrically. The amount of dye adsorbed at time $\mathrm{t}_{\mathrm{t}}\left(\mathrm{mg} \mathrm{g}^{-1}\right)$ was calculated by the following equation:

$$
q_{t}=\frac{\left(C_{0}-C_{t}\right) V}{m}
$$

...where $\mathrm{C}_{\mathrm{O}}\left(\mathrm{mg} \mathrm{L}^{-1}\right)$ is the initial dye concentration, $\mathrm{C}_{\mathrm{t}}\left(\mathrm{mg} \mathrm{L}^{-1}\right)$ the dye concentration at any time $\mathrm{t}, \mathrm{V}(\mathrm{L})$ the volume of the solution, and $\mathrm{m}(\mathrm{g})$ the mass of the adsorbent. Each experiment was carried out in duplicate and the average results are presented. The kinetic and isotherm models were evaluated by the linear correlation coefficient $\left(\mathrm{R}^{2}\right)$.

\section{Results and Discussion}

\section{Characterizing the Adsorbent}

Fig. 2 shows the XRD patterns of MWCNTs and MWCNTs-MOD. Both patterns exhibit a single characteristic strong and sharp peak at $26.2^{\circ}$. This peak is assigned to the diffraction of (002) planes of the hexagonal graphite structure corresponding to the multi-walled carbon nanotubes. The other unmarked peaks are attributed to nanocrystaline iron carbide $\mathrm{Fe}_{3} \mathrm{C}$ (JCPDS35-0772). In comparison with the pattern of MWCNT, the pattern of MWCNTs-MOD showed a small amount of $\mathrm{Fe}_{3} \mathrm{C}$.

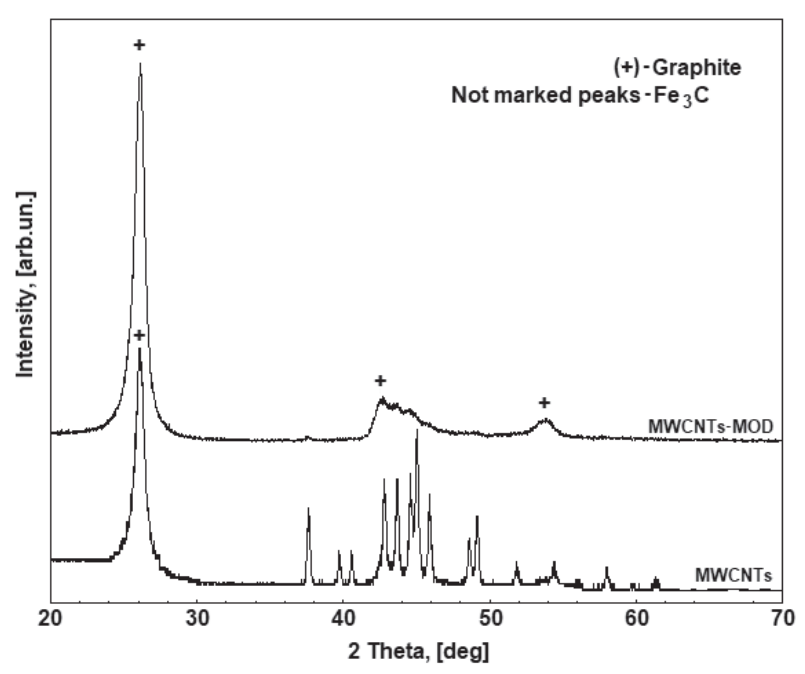

Fig. 2. X-ray diffraction patterns of MWCNTs and MWCNTsMOD. 


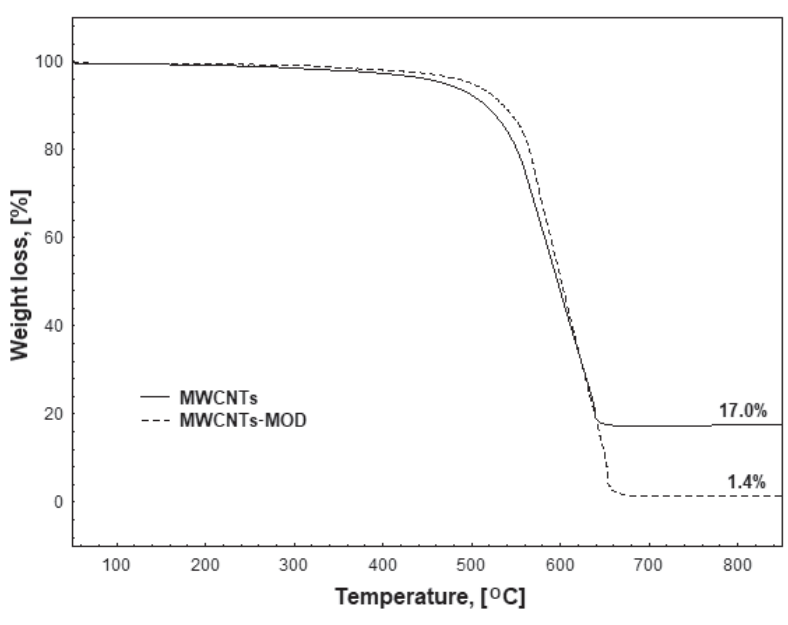

Fig. 3. TGA profiles of MWCNTs and MWCNTs-MOD.
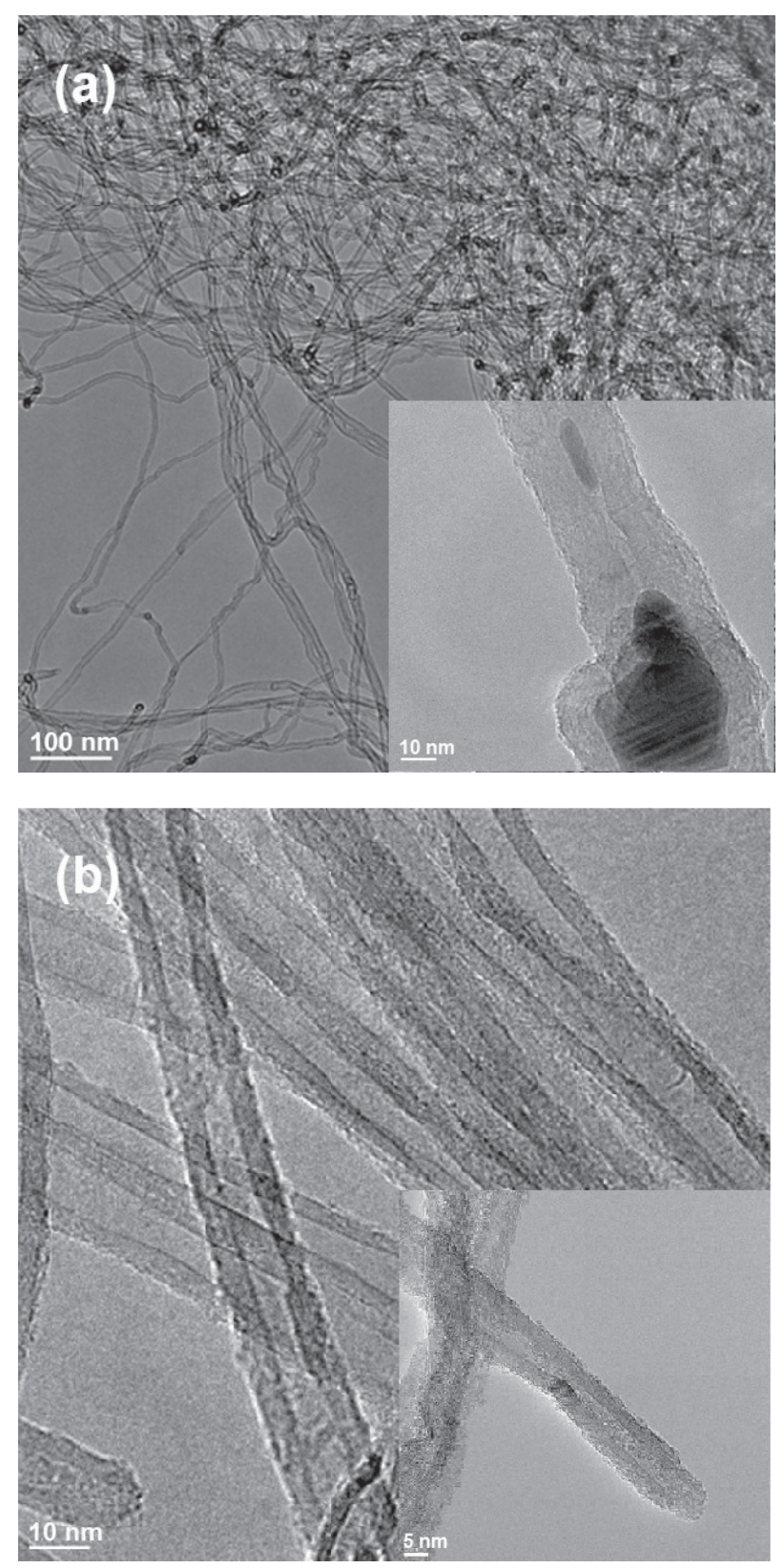

Fig. 4. HRTEM images of MWCNTs a) and MWCNTs-MOD b).

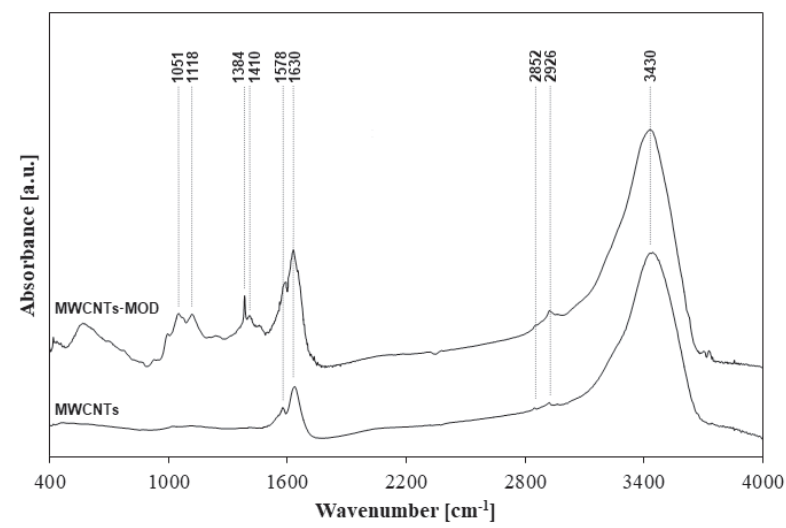

Fig. 5. FTIR spectra of MWCNTs and MWCNTs-MOD.

Fig. 3 shows TGA curves of MWCNTs and MWCNTs-MOD. Based on the obtained curves from thermogravimetric analysis content of iron in the MWCNTs and MWCNTs-MOD was calculated and equaled 17 and $1.4 \%$, respectively.

HRTEM images of MWCNTs and MWCNTs-MOD are presented in Fig. 4. Fig. 4a) shows a representative HRTEM image of MWCNTs with a large agglomeration of the long carbon nanotubes. The inset in Fig. 4a) shows that the $\mathrm{Fe}_{3} \mathrm{C}$ particles were located at the top and inside the carbon nanotubes. From Fig. 4b) we observed that after oxidation of MWCNTs, a large amount of $\mathrm{Fe}_{3} \mathrm{C}$ particles were removed.

Fig. 5 presents the FTIR spectra of MWCNTs and MWCNTs-MOD. The FTIR spectra for both samples show peaks at 1578, 1630, 2852, 2926, and $3430 \mathrm{~cm}^{-1}$. Additionally, the FTIR spectrum of MWCNTs-MOD exhibits four peaks at 1051, 1118, 1384, and $1410 \mathrm{~cm}^{-1}$. The peak at $1578 \mathrm{~cm}^{-1}$ can be ascribed to the stretching vibration of aromatic rings in the surface of MWCNTs and MWCNTs-MOD [35]. The peaks at 1630 and $3438 \mathrm{~cm}^{-1}$ are due to -OH bending and stretching vibrations respectively of adsorber water molecules [36]. The peaks at $2852 \mathrm{~cm}^{-1}$ and $2926 \mathrm{~cm}^{-1}$ are attributed

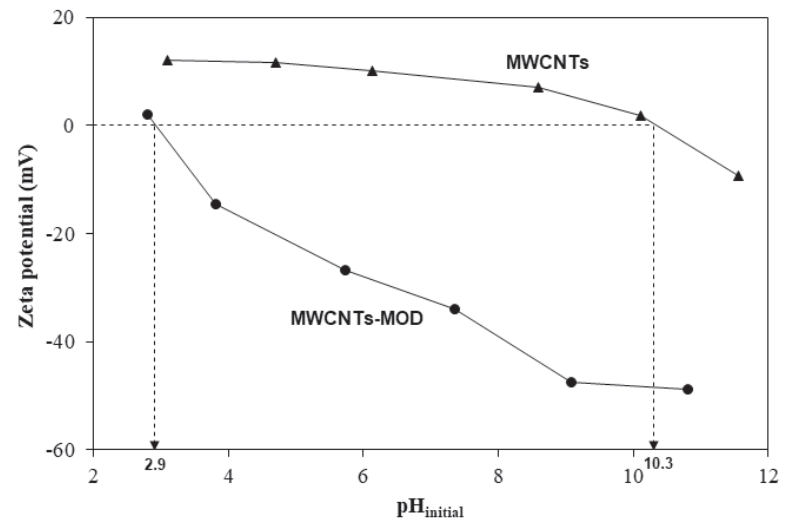

Fig. 6. Effect of $\mathrm{pH}$ on zeta potential of MWCNTs and MWCNTsMOD. 
Table 1. Physical properties of MWCNTs and MWCNTs-MOD.

\begin{tabular}{|c|c|c|c|}
\hline Adsorbent & $\begin{array}{c}\text { Specific } \\
\text { surface area } \\
\left(\mathrm{m}^{2} \mathrm{~g}^{-1}\right)\end{array}$ & $\begin{array}{c}\text { Total pore } \\
\text { volume } \\
\left(\mathrm{cm}^{3} \mathrm{~g}^{-1}\right)\end{array}$ & $\begin{array}{c}\text { Average pore } \\
\text { radius } \\
(\mathrm{nm})\end{array}$ \\
\hline MWCNTs & 38 & 0.139 & 1.76 \\
\hline MWCNTs-MOD & 51 & 0.200 & 1.76 \\
\hline
\end{tabular}

to the symmetric and asymmetric $\mathrm{C}-\mathrm{H}$ stretching vibrations in methylene groups, respectively [37]. The peaks at 1051 and $1118 \mathrm{~cm}^{-1}$ are due to the stretching vibrations of $\mathrm{C}-\mathrm{O}$ in ethers [38]. The peak at $1384 \mathrm{~cm}^{-1}$ might be attributed to the $\mathrm{O}-\mathrm{H}$ bending deformation mode in carboxyl groups [39]. The peak at $1410 \mathrm{~cm}^{-1}$ indicates the existence of symmetric stretching vibration of $\mathrm{C}=\mathrm{O}$ groups [40].

Fig. 6 shows the effect of initial $\mathrm{pH}$ on zeta potential of MWCNTs and MWCNTs-MOD. It is observed that zeta potential values of the MWCNTs-MOD are more negative than MWCNTs. When the initial $\mathrm{pH}$ was increased from 3.1 to 11.6 for MWCNTs, the zeta potentials decreased from 12.1 to $-9.2 \mathrm{mV}$. The zeta potentials of MWCNTs-MOD were measured at $\mathrm{pH}$ in the range 2.8-10.8, and decreased from 2.1 to $-48.9 \mathrm{mV}$ with increasing $\mathrm{pH}$. The point of zero charge (pHpzc) is defined as the solution $\mathrm{pH}$ at which the net surface charge of the adsorbent particle is zero. If solution $\mathrm{pH}>\mathrm{pHpzc}$, then the adsorbent surface will be predominantly negatively charged, while solution $\mathrm{pH}<\mathrm{pHpzc}$ resulted in a predominantly positively charged surface. The values of pHpzc were 10.3 and 2.9 for MWCNTs and MWCNTs-MOD, respectively. Liquid oxidation with $\mathrm{HNO}_{3}$ increases the concentration of oxygen-containing functional groups, as carboxyl $(-\mathrm{COOH})$ and hydroxyl $(-\mathrm{OH})$ groups, on the carbon surface. These acidic groups are responsible for the high acidity and the lower pHpzc value obtained for MWCNTs-MOD.

The textural parameters of the MWCNTs and MWCNTs-MOD are shown in Table 1. According to the data listed in Table 1, BET specific surface area of the MWCNTs increased after modification from 38 to $51 \mathrm{~m}^{2} \mathrm{~g}^{-1}$. Simultaneously, the total pore volume of the MWCNTs increased from 0.139 to $0.200 \mathrm{~cm}^{3} \mathrm{~g}^{-1}$. Average pore radius for both adsorbents was $1.76 \mathrm{~nm}$.

\section{Effect of Initial Dye Concentration}

Fig. 7 shows the effects of initial dye concentration on the amount of BR46 adsorbed by MWCNTs and MWCNTs-MOD at $\mathrm{pH} 7.0$ and $20^{\circ} \mathrm{C}$. As shown, the adsorption increases with increasing initial BR46 concentration, from 10.5 to $33.0 \mathrm{mg} \mathrm{g}^{-1}$ and from 24.6 to $51.5 \mathrm{mg} \mathrm{g}^{-1}$ for MWCNTs and MWCNTs-MOD, respectively.

In order to examine the mechanism and ratecontrolling step in the overall adsorption process, pseudo first-order, pseudo second-order, and intraparticle diffusion models were adopted to investigate the adsorption process. The pseudo first-order kinetic model (Eq. 2) and pseudo second-order kinetic model (Eq. 3) are given by the following equations [41]:

$$
\begin{gathered}
\ln \left(q_{e}-q_{t}\right)=\ln q_{e}-k_{1} t \\
\frac{t}{q_{t}}=\frac{1}{k_{2} q_{e}^{2}}+\frac{1}{q_{e}} t
\end{gathered}
$$

...where $\mathrm{k}_{1}\left(\mathrm{~min}^{-1}\right)$ is the pseudo first-order rate constant adsorption, $\mathrm{t}(\mathrm{min})$ time, $\mathrm{k}_{2}\left(\mathrm{~g} \mathrm{mg}^{-1} \mathrm{~min}^{-1}\right)$ is the pseudo second-order rate constant adsorption. Values of $k_{1}$ and $q_{e}$ were calculated from the linear plots of $\ln \left(\mathrm{q}_{\mathrm{e}}-\mathrm{q}_{\mathrm{f}}\right)$ versus $\mathrm{t}$. Values of $\mathrm{k}_{2}$ and $\mathrm{q}_{\mathrm{e}}$ were calculated from the slope and intercept of the linear plots obtained by graphical representation of $t / q_{t}$ versus $t$ (Fig. 8). As can be seen from the results given in Table 2, correlation coefficients $\left(\mathrm{R}^{2} \geq 0.998\right)$ for the pseudo second-order kinetic model are higher in comparison with the pseudo first-order kinetic model, and the calculated values of $\mathrm{q}_{\mathrm{e}, \mathrm{cal}}$ from the pseudo second-order kinetic model are very close to the experimental values $\left(\mathrm{q}_{\mathrm{e}, \mathrm{exp}}\right)$ for both adsorbents. These results mentioned above indicate that the adsorption process follows the pseudo
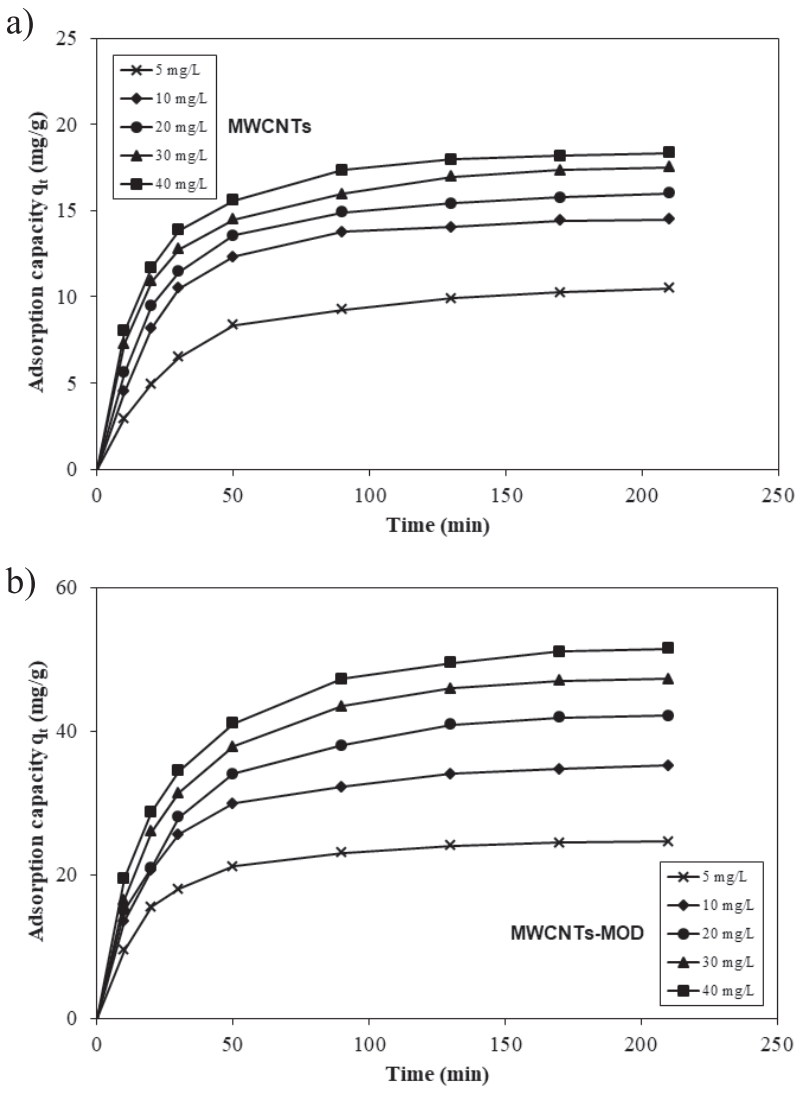

Fig. 7. Effect of initial dye concentration on adsorption capacity of BR46 onto MWCNTs a), and MWCNTs-MOD b) (experimental conditions: $\mathrm{T}=20^{\circ} \mathrm{C}, \mathrm{pH}=7$ ). 

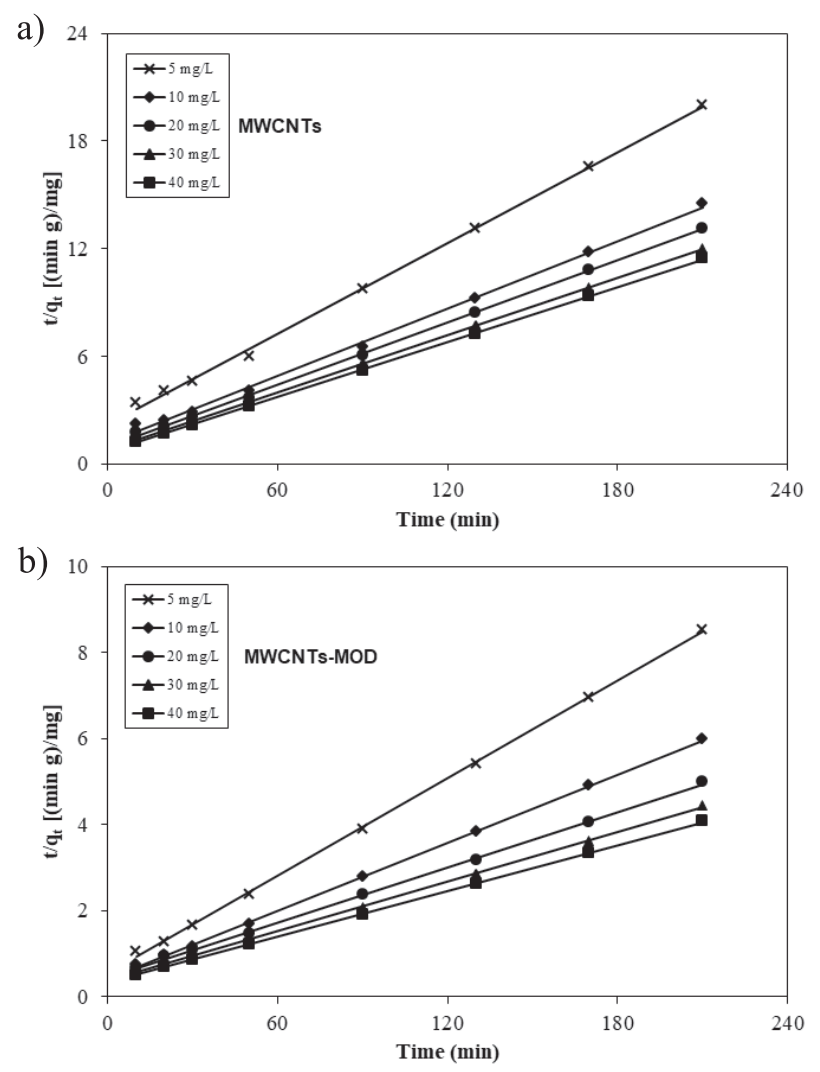

Fig. 8. Pseudo second-order kinetics of adsorption BR46 onto MWCNTs a), and MWCNTs-MOD b) (experimental conditions: $\mathrm{T}=20^{\circ} \mathrm{C}, \mathrm{pH}=7$ ).

second-order model rather than pseudo first-order kinetic model.

The kinetic data were also treated with the following intraparticle diffusion rate equation [42]:

$$
q_{t}=k_{p} t^{0.5}+C
$$

...where $\mathrm{k}_{\mathrm{p}}\left(\mathrm{mg} \mathrm{g}^{-1} \min ^{-0.5}\right)$ is the intraparticle diffusion rate constant and $\mathrm{C}\left(\mathrm{mg} \mathrm{g}^{-1}\right)$ is a constant related to the thickness of the boundary layer. According to this model, if the plot of $q_{t}$ versus $t^{0.5}$ is linear and passes through the origin, then intraparticle diffusion is the sole rate-limiting step. The plots of $\mathrm{q}_{\mathrm{t}}$ versus $\mathrm{t}^{0.5}$ (Fig. 9) were multi-linear and there were two different portions, indicating the different stages in adsorption. The first, sharper portion represents the external mass transfer. The second portion is the gradual adsorption stage, where intraparticle diffusion is rate-limiting. The lines do not pass through the origin $(\mathrm{C} \neq 0)$, which indicates that the intraparticle diffusion is involved in the adsorption process but not the only rate-controlling step.

The values of $\mathrm{k}_{\mathrm{p}}$ and $\mathrm{C}$ were determined from the slopes of the second linear portion, and the constants of intraparticle diffusion model are given in Table 2 . The values of $\mathrm{C}$ were helpful in determining the boundary thickness: a larger $\mathrm{C}$ value corresponded to a greater boundary layer diffusion effect. The $\mathrm{C}$ values for both

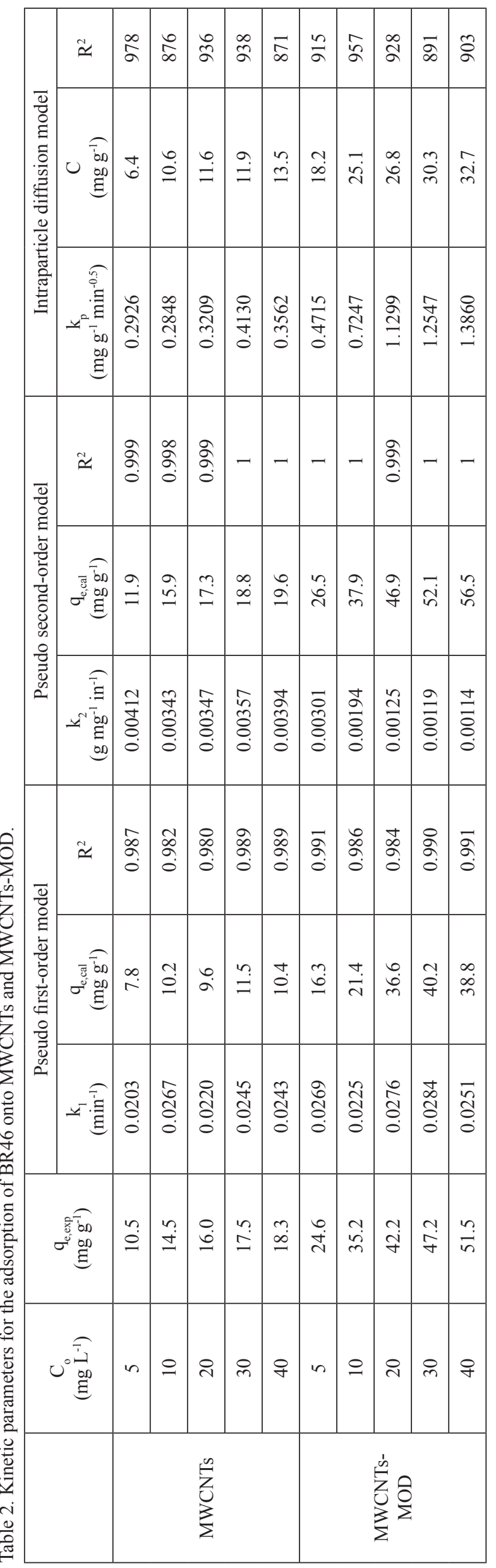


adsorbents increased with the initial dye concentration. The results of this study demonstrated that increasing the concentration promoted the boundary layer diffusion effect.

\section{Adsorption Isotherms}

Equilibrium adsorption isotherm data were analyzed according to the Langmuir and Freundlich models. The linearized form of the Langmuir equation is given by the following equation [43]:

$$
\frac{C_{e}}{q_{e}}=\frac{1}{Q_{0} b}+\frac{C_{e}}{Q_{0}}
$$

...where $\mathrm{Q}_{\mathrm{O}}\left(\mathrm{mg} \mathrm{g}^{-1}\right)$ is the monolayer adsorption capacity and $b\left(\mathrm{~L} \mathrm{mg}^{-1}\right)$ is a constant related to energy of adsorption. The values of $\mathrm{Q}_{\mathrm{O}}$ and $\mathrm{b}$ were calculated from the slope and intercept of the linear plot $\mathrm{C}_{\mathrm{e}} / \mathrm{q}_{\mathrm{e}}$ versus $\mathrm{C}_{\mathrm{e}}$ (Fig. 10a). The essential characteristics of the Langmuir isotherm can be expressed in terms of dimensionless equilibrium parameter $\left(R_{L}\right)$, which is defined by the following equation:

$$
R_{L}=\frac{1}{1+b C_{O}}
$$

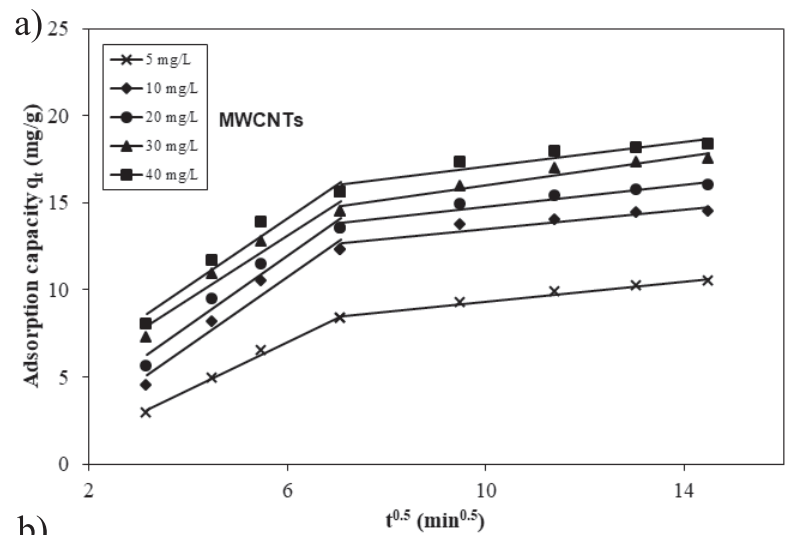

b)

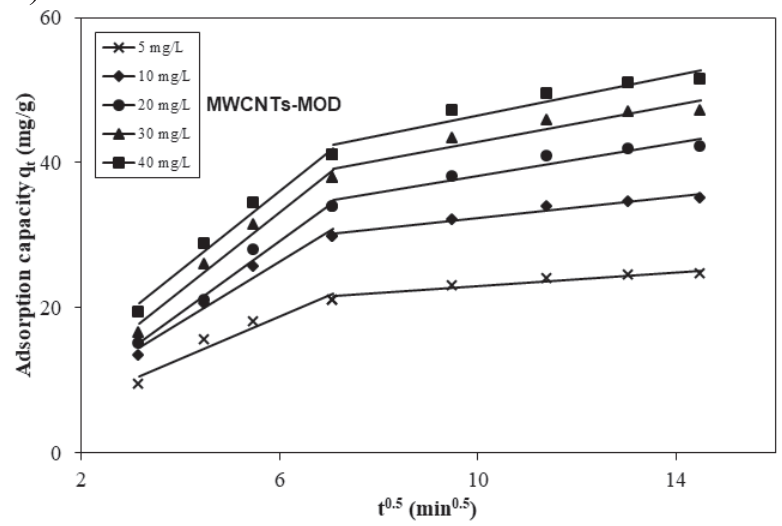

Fig. 9. Intraparticle diffusion model of adsorption BR46 onto MWCNTs a), and MWCNTs-MOD b) (experimental conditions: $\mathrm{T}=20^{\circ} \mathrm{C}, \mathrm{pH}=7$ ). ...where $\mathrm{b}\left(\mathrm{L} \mathrm{mg}^{-1}\right)$ is the Langmuir constant and $\mathrm{C}_{\mathrm{O}}$ (mg L $\left.\mathrm{L}^{-1}\right)$ is the highest initial concentration of the adsorbate. The value of $R_{L}$ indicates the type of the isotherm to be either unfavorable $\left(R_{L}>1\right)$, linear $\left(R_{L}=1\right)$, favorable $\left(0<R_{L}<1\right)$, or irreversible $\left(R_{L}=0\right)$.

The linear form of the Freundlich equation can be described as [44]:

$$
\ln q_{e}=\ln K_{F}+\left(\frac{1}{n}\right) \ln C_{e}
$$

...where $\mathrm{K}_{\mathrm{F}}\left(\mathrm{mg} \mathrm{g}^{-1}\left(\mathrm{~L} \mathrm{mg}^{-1}\right)^{1 / \mathrm{n}}\right)$ and $\mathrm{n}$ are Freundlich constants, which represent adsorption capacity and adsorption strength, respectively. The values of $K_{F}$ and $n$ were calculated from the slope and intercept of the linear plot $\ln \mathrm{q}_{\mathrm{e}}$ versus $\ln \mathrm{C}_{\mathrm{e}}$ (Fig. 10b). The value of $\mathrm{n}$ ranging from 1 to 10 indicated that the adsorption process is favourable.

The calculated parameters for Langmuir and Freundlich isotherms and the correlation coefficients $\mathrm{R}^{2}$ are listed in Table 3. From Table 3, the Langmuir isotherm model yielded better fit with higher $\mathrm{R}^{2}$ values compared to the Freundlich model. Additionally, the calculated values of $R_{L}$ were found between 0 and 1. This implies that the adsorption of BR46 onto MWCNTs and MWCNTs-MOD from aqueous solutions is favorable under the conditions used in
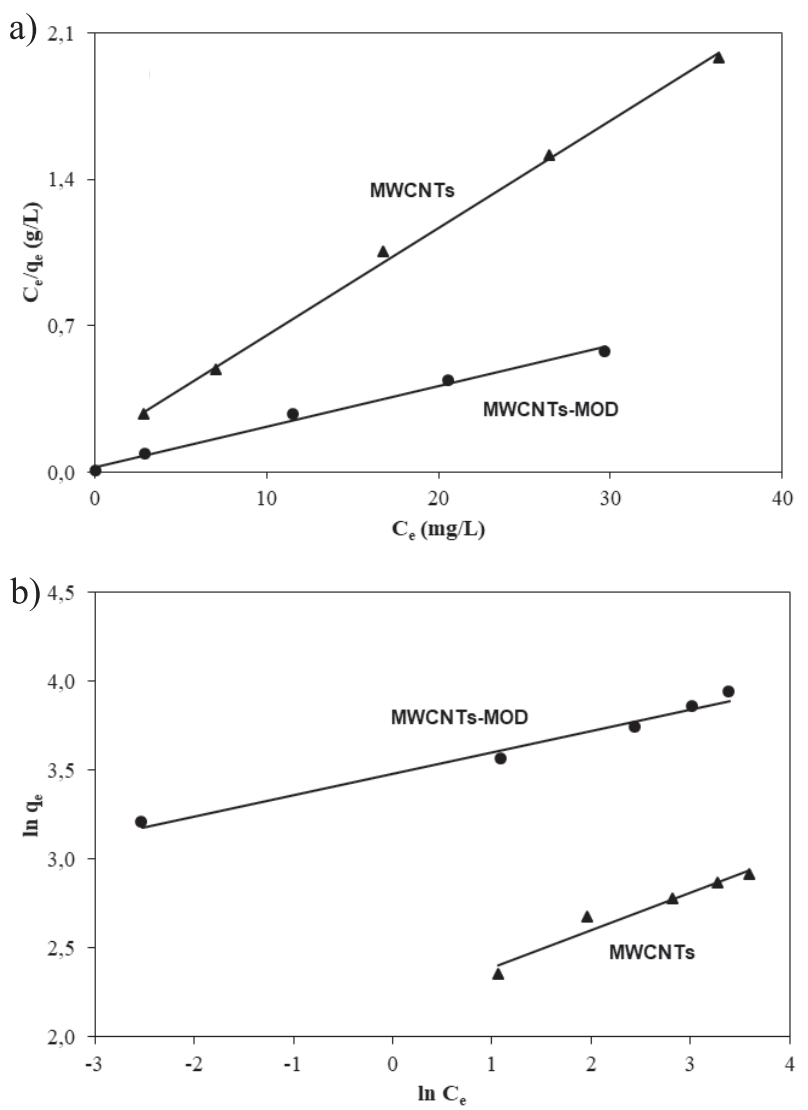

Fig. 10. Langmuir a) and Freundlich b) isotherms for BR46 adsorption onto MWCNTs and MWCNTs-MOD at $\mathrm{T}=20^{\circ} \mathrm{C}$. 
Table 3. Langmuir and Freundlich parameters for the adsorption of BR46 onto MWCNTs and MWCNTs-MOD.

\begin{tabular}{|c|c|c|c|c|c|c|c|}
\hline & \multicolumn{3}{|c|}{ Langmuir isotherm } & \multicolumn{3}{c|}{ Freundlich isotherm } \\
\cline { 2 - 8 } & $\begin{array}{c}\mathrm{Q}_{\mathrm{O}} \\
\left(\mathrm{mg} \mathrm{g}^{-1}\right)\end{array}$ & $\begin{array}{c}\mathrm{b} \\
\left(\mathrm{L} \mathrm{mg}^{-1}\right)\end{array}$ & $\mathrm{R}_{\mathrm{L}}$ & $\mathrm{R}^{2}$ & $\begin{array}{c}\mathrm{K}_{\mathrm{F}} \\
{\left[\left(\mathrm{mg} \mathrm{g}^{-1}\right)\left(\mathrm{L} \mathrm{mg}^{-1}\right)^{1 / \mathrm{n}}\right]}\end{array}$ & $\mathrm{n}$ & $\mathrm{R}^{2}$ \\
\hline MWCNTs & 19.5 & 0.359 & 0.07 & 0.998 & 8.85 & 4.77 & 0.948 \\
\hline MWCNTs-MOD & 51.8 & 0.781 & 0.03 & 0.992 & 32.5 & 8.32 & 0.979 \\
\hline
\end{tabular}

Table 4. Comparison of the maximum monolayer adsorption of BR46 onto various adsorbents.

\begin{tabular}{|c|c|c|}
\hline Adsorbent & $\mathrm{Q}_{\mathrm{O}}\left(\mathrm{mg} \mathrm{g}^{-1}\right)$ & Ref. \\
\hline MWCNTs & 19.5 & This study \\
\hline Princess tree leaf & 43.1 & {$[45]$} \\
\hline MWCNTs-MOD & 51.8 & This study \\
\hline Moroccan crude clay & 54.0 & {$[46]$} \\
\hline Graphene oxide & 76.9 & {$[47]$} \\
\hline Activated carbon & 714.28 & {$[48]$} \\
\hline
\end{tabular}

this study. The maximum monolayer adsorption capacities of the adsorbents were 19.5 and $51.8 \mathrm{mg}$ $\mathrm{g}^{-1}$ for MWCNTs and MWCNTs-MOD, respectively. Table 4 summarizes the adsorption capacity of BR46 onto various absorbents.

\section{Effect of Initial $\mathrm{pH}$}

The $\mathrm{pH}$ of the aqueous solution is an important factor controlling dye adsorption. Therefore, the effect of initial $\mathrm{pH}$ on adsorption of BR46 onto MWCNTs and MWCNTs-MOD was studied in the $\mathrm{pH}$ range of 4.0 to 11.5 at $20^{\circ} \mathrm{C}$ and initial dye concentration of $20 \mathrm{mg} \mathrm{L}^{-1}$ (Fig. 11). As can be observed in Fig. 11, when the initial $\mathrm{pH}$ of the dye solution was increased from 4.0 to 11.5 , the adsorption capacity increased from 14.8 to $23.5 \mathrm{mg} \mathrm{g}^{-1}$ and from 31.4 to $57.2 \mathrm{mg} \mathrm{g}^{-1}$ for MWCNTs

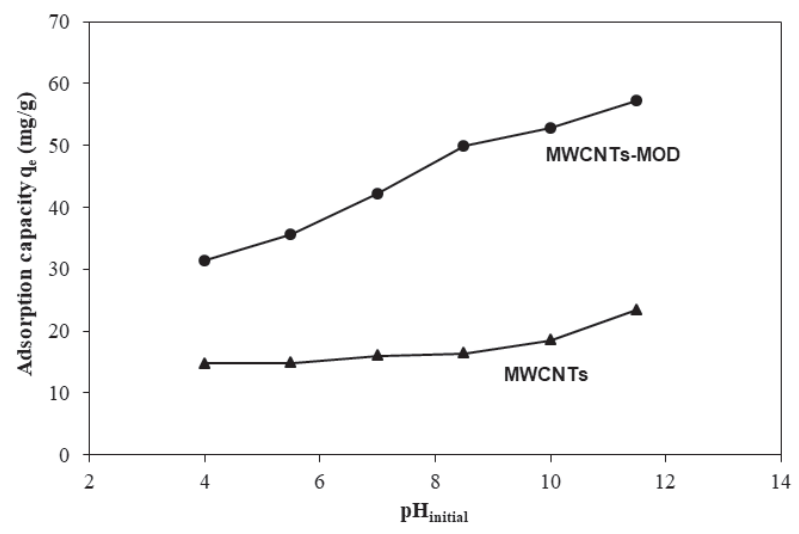

Fig. 11. Effect of initial $\mathrm{pH}$ of dye solution on adsorption capacity of the BR46 onto MWCNTs a), and MWCNTs-MOD b) (experimental conditions: $\mathrm{C}_{\mathrm{BR} 46}^{\mathrm{O}}=20 \mathrm{mg} \mathrm{L}^{-1}, \mathrm{~T}=20^{\circ} \mathrm{C}$ ). and MWCNTs-MOD, respectively.

The effect of $\mathrm{pH}$ on adsorption of BR46 onto both adsorbents can be explained on the basis of the point of zero charge $\mathrm{pHpzc}$. The pHpzc of MWCNTs was found to be 10.3 (Fig. 6). The adsorbent surface has a net positive charge at $\mathrm{pH}<\mathrm{pHpzc}$, while it has net negative charge at $\mathrm{pH}>\mathrm{pHpzc}$. At lower $\mathrm{pH}$ values, due to the protonation of electron $\pi$ rich regions on the surface of multiwalled carbon nanotubes, the positive surface charge can be formed [49]. Under these conditions, positively charged surface sites on MWCNTs generate electrostatic repulsion force with cationic dyes. When the $\mathrm{pH}$ of the dye solution increases, the number of negatively charged sites on MWCNTs increases and favors the adsorption of BR46 by electrostatic attraction.

The zeta potential values of the MWCNTs-MOD are more negative in comparison to MWCNTs. Results showed that the zeta potentials of MWCNTs-MOD
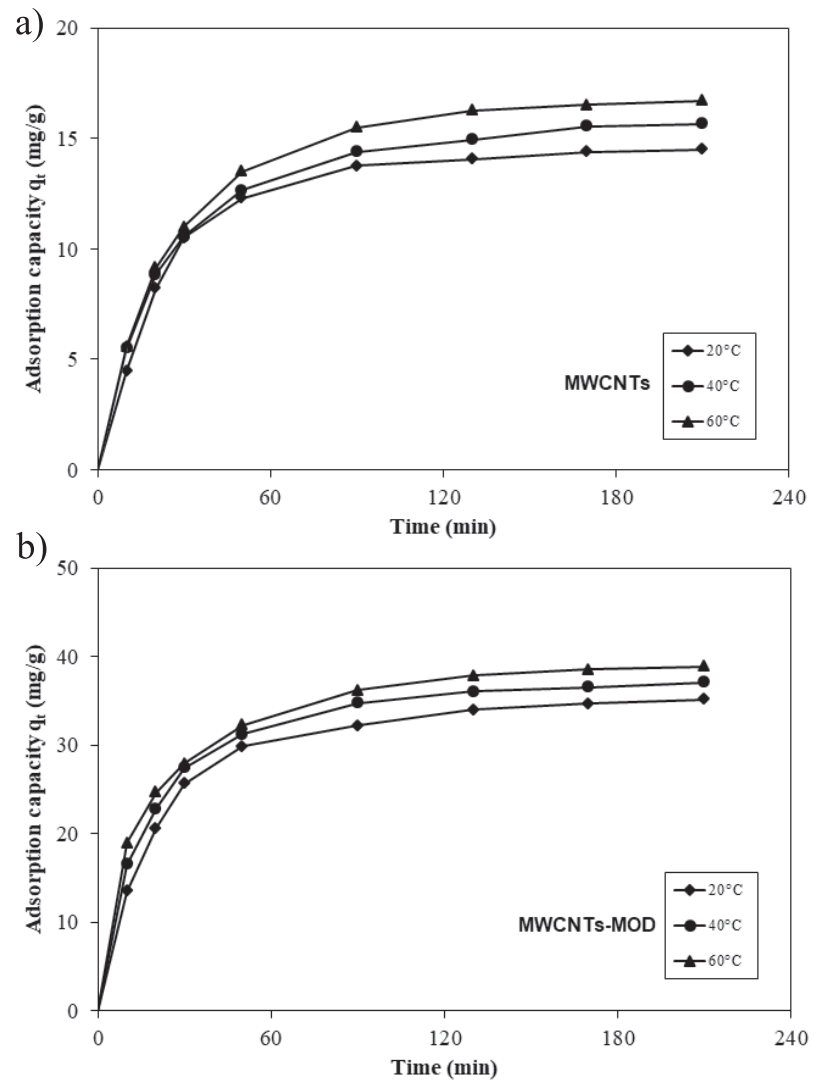

Fig. 12. Effect of temperature on adsorption capacity of BR46 onto MWCNTs a), and MWCNTs-MOD b) (experimental conditions: $\mathrm{C}_{\mathrm{BR} 46}^{\mathrm{O}}=10 \mathrm{mg} \mathrm{L}^{-1}, \mathrm{pH}=7$ ). 


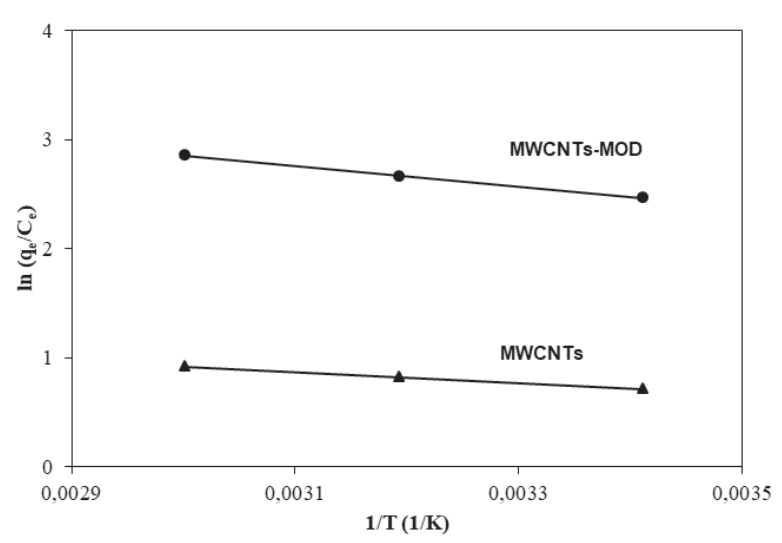

Fig. 13. Van't Hoff plot for the adsorption of BR46 onto MWCNTs and MWCNTs-MOD.

decreased from 2.1 to $-48.9 \mathrm{mV}$ with the increase of $\mathrm{pH}$ value from 2.8 to 10.8. The pHpzc of MWCNTs-MOD was found to be 2.9 , at which the adsorbent is neutral. The surface of MWCNTs-MOD is negatively charged due to the presence of a large amount of oxygen-containing functional groups, as carboxyl $(-\mathrm{COOH})$ and hydroxyl $(-\mathrm{OH})$ groups, on the surface. At acidic $\mathrm{pH}$, these groups are protonated to the cationic form $\left(-\mathrm{COOH}_{2}^{+}\right.$and $\left.-\mathrm{OH}_{2}^{+}\right)$ and generate electrostatic repulsion force with BR46 cations. When the $\mathrm{pH}$ of the dye solution increases, carboxylic and hydroxylic groups dissociate to anionic form $\left(-\mathrm{COO}^{-}\right.$and $\left.{ }^{-} \mathrm{O}^{-}\right)$, and the number of negatively charged sites increases, which favors the adsorption of positively charged BR46 ions because of the electrostatic force of attraction. Therefore, adsorption of BR46 onto the MWCNTs-MOD surface is much higher at basic $\mathrm{pH}$.

\section{Effect of Temperature}

The effect of temperature on adsorption capacity of BR46 onto MWCNTs and MWCNTs-MOD was investigated at 20,40 , and $60^{\circ} \mathrm{C}$, and the results are presented in Fig. 12. The experimental results show that the adsorption capacity increased with increase in the solution temperature for both adsorbents. This indicated that the adsorption of BR46 onto MWCNTs and MWCNTs-MOD is endothermic in nature.

Thermodynamic parameters such as a change in free energy $\left(\Delta \mathrm{G}^{\mathrm{O}}\right)$, enthalpy $\left(\Delta \mathrm{H}^{\circ}\right)$, and entropy $\left(\Delta \mathrm{S}^{\mathrm{O}}\right)$, were determined using the following equations [50]:

$$
\begin{gathered}
\ln K_{a}=\frac{\Delta S^{o}}{R}-\frac{\Delta H^{o}}{R \cdot T} \\
K_{a}=\frac{q_{e}}{C_{e}} \\
\Delta G^{o}=-R T \ln K_{a}
\end{gathered}
$$

...where $\mathrm{T}(\mathrm{K})$ is the solution temperature and $\mathrm{K}_{\mathrm{a}}$ is the adsorption equilibrium constant. Enthalpy $\left(\Delta \mathrm{H}^{\mathrm{O}}\right)$ and entropy $\left(\Delta \mathrm{S}^{\circ}\right)$ were calculated from the slope and intercept from the plot of $\ln \mathrm{q}_{\mathrm{e}} / \mathrm{C}_{\mathrm{e}}$ versus $1 / \mathrm{T}$ (Fig. 13). The value of Gibbs free energy $\left(\Delta \mathrm{G}^{\circ}\right)$ was calculated using Eq. 10. Table 5 shows the thermodynamic parameters for BR46 adsorption onto MWCNTs and MWCNTs-MOD. The positive values of $\Delta \mathrm{H}^{\mathrm{O}}$ indicate the endothermic nature of the adsorption process, while the positive values of $\Delta S^{O}$ suggest the increased randomness at solid/liquid interface during the adsorption process of BR46 onto MWCNTs and MWCNTs-MOD. It has been reported that the $\Delta \mathrm{H}^{\mathrm{O}}$ of physisorption is smaller than $40 \mathrm{~kJ} \mathrm{~mol}^{-1}$ [51]. In this study the values of $\Delta \mathrm{H}^{\mathrm{O}}$ were 4.2 and $7.8 \mathrm{~kJ} \mathrm{~mol}^{-1}$ for MWCNTs and MWCNTs-MOD, respectively. The values of $\Delta \mathrm{G}^{\mathrm{O}}$ decreased from -1.74 to $-2.55 \mathrm{~kJ} \mathrm{~mol}^{-1}$ for MWCNTs and from -6.02 to $-7.92 \mathrm{~kJ}$ $\mathrm{mol}^{-1}$ for MWCNTs-MOD, indicating that the adsorption process is spontaneous and thermodynamically favorable. Generally, the change in free energy $\left(\Delta \mathrm{G}^{\mathrm{O}}\right)$ for physisorption is in the range of -20 and $0 \mathrm{~kJ} \mathrm{~mol}^{-1}$, but chemisorption is between -80 to $-400 \mathrm{~kJ} \mathrm{~mol}^{-1}$ [52]. The values of $\Delta \mathrm{G}^{\mathrm{O}}$ are within the range of -20 to $0 \mathrm{~kJ} \mathrm{~mol}^{-1}$, indicating physisorption as the predominant mechanism of the adsorption process.

\section{Conclusions}

In this work, as-grown (MWCNTs) and modified multi-walled carbon nanotubes (MWCNTs-MOD) have been used as adsorbents for the removal of the cationic dye Basic Red 46 (BR46) from aqueous solution. Batch adsorption experiments were investigated by various parameters such as initial dye concentration, $\mathrm{pH}$, and temperature. The adsorption of BR46 onto both adsorbents followed the pseudo second-order kinetic

\begin{tabular}{|c|c|c|c|c|c|c|}
\hline & $\begin{array}{c}\Delta \mathrm{H}^{\mathrm{O}} \\
\left(\mathrm{kJ} \mathrm{mol}^{-1}\right)\end{array}$ & $\begin{array}{c}\Delta \mathrm{S}^{\mathrm{O}} \\
\left(\mathrm{J} \mathrm{mol}^{-1} \mathrm{~K}^{-1}\right)\end{array}$ & & $\begin{array}{l}\text { mperat } \\
\mathrm{J} \mathrm{mol}^{-1}\end{array}$ & & $\mathrm{R}^{2}$ \\
\hline \multirow{2}{*}{ MWCNTs } & \multirow{2}{*}{4.2} & \multirow{2}{*}{20.5} & 20 & 40 & 60 & \multirow{2}{*}{0.999} \\
\hline & & & -1.74 & -2.14 & -2.55 & \\
\hline \multirow{2}{*}{ MWCNTs-MOD } & \multirow{2}{*}{7.8} & \multirow{2}{*}{47.2} & 20 & 40 & 60 & \multirow{2}{*}{0.998} \\
\hline & & & -6.02 & -6.93 & -7.92 & \\
\hline
\end{tabular}
model and intraparticle diffusion model, indicating that

Table 5. Thermodynamic parameters for the adsorption of BR46 onto MWCNTs and MWCNTs-MOD. 
intraparticle diffusion was not the rate-limiting step. The equilibrium adsorption behavior of BR46 onto MWCNTs and MWCNTs-MOD followed the Langmuir adsorption isotherm with a maximum adsorption capacity of 19.5 and $51.8 \mathrm{mg} \mathrm{g}^{-1}$, respectively. The thermodynamic parameters showed that the adsorption of BR46 onto MWCNTs and MWCNTs-MOD was a spontaneous and endothermic process. Thermodynamic studies also indicated that adsorption is mainly a physisorption process.

\section{Acknowledgements}

The authors are grateful to Dr. A. Jędrzejewska (Institute of Chemical and Environmental Engineering, West Pomeranian University of Technology, Szczecin) for measurements using high-resolution transmission electron microscopy.

\section{Conflict of Interest}

The authors declare no conflict of interest.

\section{Referencess}

1. BAYRAMOGLU G., ALTINTAS B., ARICA M.Y. Adsorption kinetics and thermodynamic parameters of cationic dyes from aqueous solutions by using a new strong cation-exchange resin. Chem. Eng. J. 152, 339, 2009.

2. MOGHADDAM S.S., MOGHADDAM M.R.A, ARAMI M. Coagulation/flocculation process for dye removal using sludge from water treatment plant: Optimization through response surface methodology. J. Hazard. Mater. 175 (1-3), 651, 2010.

3. BOURAIE M.E., DIN W.S.E. Biodegradation of Reactive Black 5 by Aeromonas hydrophila strain isolated from dyecontaminated textile wastewater. Sustain. Environ. Res. 26 (5), 209, 2016.

4. YAGUB M.T., SEN T.K., AFROZE S., ANG H.M. Dye and its removal from aqueous solution by adsorption: A review. Adv. Colloid Interface Sci. 209, 172, 2014.

5. MOHAMMADI N., KHANI H., GUPTA V.K., AMEREH E., AGARWAL S. Adsorption process of methyl orange dye onto mesoporous carbon material-kinetic and thermodynamic studies. J. Colloid Interface Sci. 362(2), 457, 2011.

6. GUPTA V.K., KUMAR R., NAYAK A., SALEH T.A., BARAKAT M.A. Adsorptive removal of dyes from aqueous solution onto carbon nanotubes: a review. Adv. Colloid Interface Sci. 193-194, 24, 2013.

7. JIRANKOVA H., MRAZEK J., DOLECEK P., CAKL J. Organic dye removal by combined adsorption-membrane separation process. Desalin. Water Treat. 20, 96, 2010.

8. RALIYA R., AVERY C., CHAKRABARTI S., BISWAS P. Photocatalytic degradation of methyl orange dye by pristine titanium dioxide, zinc oxide, and graphene oxide nanostructures and their composites under visible light irradiation. Appl. Nanosci. 7 (5), 253, 2017.
9. GUPTA V.K., JAIN R., MITTAL A., SALEH T.A., NAYAK A., AGARWAL S., SIKARWAR S. Photocatalytic degradation of toxic dye amaranth on $\mathrm{TiO}_{2} / \mathrm{UV}$ in aqueous suspensions. Mater. Sci. Eng. C. 32 (1), 12, 2012.

10. SARAVANAN R., KARTHIKEYAN S., GUPTA V.K., SEKARAN G., NARAYANAN V., STEPHEN A. Enhanced photocatalytic activity of $\mathrm{ZnO} / \mathrm{CuO}$ nanocomposite for the degradation of textile dye on visible light illumination. Mater. Sci. Eng. C. 33, 91, 2013.

11. KASIRI M.B., MODIRSHAHLA N., MANSOURI H. Decolorization of organic dye solution by ozonation; Optimization with response surface methodology. Int. J. Ind. Chem. 4 (3), 1, 2013.

12. PATHANIA D., SHARMA S., SINGH P. Removal of methylene blue by adsorption onto activated carbon developed from Ficus carica bast. Arabian J. Chem. 10, S1445, 2017.

13. VAKILI M., RAFATULLAH M., SALAMATINIA B., ABDULLAH A.Z., IBRAHIM M.H., TAN K.B., GHOLAMI Z., AMOUZGAR P. Application of chitosan and its derivatives as adsorbents for dye removal from water and wastewater: A review. Carbohydr. Polym. 113, $115,2014$.

14. KUO C.Y., WU C.H., WU J.Y. Adsorption of direct dyes from aqueous solutions by carbon nanotubes: Determination of equilibrium, kinetics and thermodynamics parameters. J. Colloid Interface Sci. 327, 308, 2008.

15. RAMESHA G.K., KUMARA A.V., MURALIDHARA H.B., SAMPATH S. Graphene and graphene oxide as effective adsorbents toward anionic and cationic dyes. J. Colloid Interface Sci. 361, 270, 2011.

16. WANG S., LI H., XU L. Application of zeolite MCM-22 for basic dye removal from wastewater. J. Colloid Interface Sci. 295 (1), 71, 2006.

17. ELASS K., LAACHACH A., ALAOUI A., AZZI M. Removal of methyl violet from aqueous solution using a stevensite-rich clay from Morocco. Appl. Clay Sci. 54, 90, 2011.

18. JANHOM S., WATANESK R., WATANESK S., GRIFFITHS P., ARQUERO O.A., NAKSATA W. Comparative study of lac dye adsorption on cotton fibre surface modified by synthetic and natural polymers. Dyes Pigments 71 (3), 188, 2006.

19. ARAMI M., LIMAEE N.Y., MAHMOODI N.M., TABRIZI N.S. Removal of dyes from colored textile wastewater by orange peel adsorbent: Equilibrium and kinetic studies. J. Colloid Interface Sci. 288 (2), 371, 2005.

20. ZENG S., DUAN S., TANG R., LI L., LIU C., SUN D. Magnetically separable $\mathrm{Ni}_{0.6} \mathrm{Fe}_{2.4} \mathrm{O}_{4}$ nanoparticles as an effective adsorbent for dye removal: Synthesis and study on the kinetic and thermodynamic behaviors for dye adsorption. Chem. Eng. J. 258, 218, 2014.

21. SUN D., ZHANG X., WU Y., LIU X. Adsorption of anionic dyes from aqueous solution on fly ash. J. Hazard. Mater. 181, 335, 2010.

22. QU S., HUANG F., YU S., CHEN G., KONG J. Magnetic removal of dyes from aqueous solution using multi-walled carbon nanotubes filled with $\mathrm{Fe}_{2} \mathrm{O}_{3}$ particles. J. Hazard. Mater. 160, 643, 2008.

23. GONG J.L., WANG B., ZENG G.M., YANG C.P., NIU C.G., NIU Q.Y, ZHOU W.J., LIANG Y. Removal of cationic dyes from aqueous solution using magnetic multi-wall carbon nanotube nanocomposite as adsorbent. J. Hazard. Mater. 164, 1517, 2009.

24. GAO H., ZHAO S., CHENG X., WANG X., ZHENG L. Removal of anionic azo dyes from aqueous solution 
using magnetic polymer multi-wall carbon nanotube nanocomposite as adsorbent. Chem. Eng. J. 223, 84, 2013.

25. KUO C.Y, WU C.H., WU J.Y. Adsorption of direct dyes from aqueous solutions by carbon nanotubes: Determination of equilibrium, kinetics and thermodynamics parameters. J. Colloid Interface Sci. 327, 308, 2008.

26. YAO Y., XU F., CHEN M., XU Z., ZHU Z. Adsorption behavior of methylene blue on carbon nanotubes. Bioresour. Technol. 101, 3040, 2010.

27. YAO Y., HE B., XU F., CHEN X. Equilibrium and kinetic studies of methyl orange adsorption on multi-walled carbon nanotubes. Chem. Eng. J. 170, 82, 2011.

28. WANG S., NG C.W., WANG W., LI Q., HAO Z. Synergistic and competitive adsorption of organic dyes on multi-walled carbon nanotubes. Chem. Eng. J. 197, 34, 2012.

29. GHAEDI M., KOKHDAN S.N. Oxidized multi walled carbon nanotubes for the removal of methyl red (MR): kinetics and equilibrium study. Desalin. Water Treat. 49, 317, 2012.

30. GHAEDI M., KHAJEHSHARI H., YADKURI A.H., ROOSTA M., ASGHARI A. Oxidized multi-walled carbon nanotubes as efficient adsorbent for bromothymol blue. Toxicol. Environ. Chem. 94, 873, 2012.

31. MISHRA A.K., AROCKIADOSS T., RAMAPRABHU S. Study of removal of azo dye by functionalized multi walled carbon nanotubes. Chem. Eng. J. 162, 1026, 2010.

32. SHEIBANI M., GHAEDI M., MARAHEL F., ANSARI A. Congo red removal using oxidized multi-walled carbon nanotubes: kinetic and isotherm study. Desalin. Water Treat. 53 (3), 844, 2015.

33. DUMAN O., TUNÇ S., POLAT T.G., BOZOĞLAN B.K. Synthesis of magnetic oxidized multi-walled carbon nanotube-k-carrageenan- $\mathrm{Fe}_{3} \mathrm{O}_{4}$ nanocomposite adsorbent and its application in cationic Methylene Blue dye adsorption. Carbohydr. Polym. 147, 79, 2016.

34. PEŁECH I. Preparation of carbon nanotubes using CVD method. Pol. J. Chem. Tech. 12 (3), 45, 2010.

35. CHEN J., CHEN Q., MA Q., LI Y., ZHU Z. Chemical treatment of CNTs in acidic $\mathrm{KMnO}_{4}$ solution and promoting effects on the corresponding Pd-Pt/CNTs catalyst. J. Mol. Catal. A: Chem. 356, 114, 2012.

36. ANKU W.W, OPPONG S.O.B., SHUKLA S.K., AGORKU E.S, GOVENDER P.P Cobalt doped $\mathrm{ZrO}_{2}$ decorated multiwalled carbon nanotube: A promising nanocatalyst for photodegradation of indygo carmine and eosin Y dyes. Prog. Nat. Sci. 26, 354, 2016.

37. COATES J.P. A Practical Approach to the Interpretation of Infrared Spectra. Encyclopedia of Analytical Chemistry, John Wiley \& Sons Ltd., Chichester, 2000.

38. CHEN J., ZHU Z.H., MA Q., LI L., RUDOLPH V., LU G.Q. Effects of pre-treatment in air microwave plasma on the structure of CNTs and the activity of Ru/CNTs catalysts for ammonia decomposition. Catal. Today 148, 97, 2009.

39. KOLACYAK D., IHDE J., MERTEN C., HARTWIG A., LOMMATZSCH U. Fast functionalization of multi-walled carbon nanotubes by an atmospheric pressure plasma jet. J. Colloid Interface Sci. 359, 311, 2011.

40. WU S., ZHAO X., LI Y., DU Q., SUN J., WANG Y., WANG X., XIA Y., WANG Z., XIA L. Adsorption Properties of Doxorubicin Hydrochloride onto Graphene Oxide: Equilibrium, Kinetic and Thermodynamic Studies. Materials 6, 2026, 2013.

41. LI L., LIU S., ZHU T. Application of activated carbon derived from scrap tires for adsorption of Rhodamine B. J. Environ. Sci. 22 (8), 1273, 2010.

42. WEBER W.J., MORRIS J.C. Kinetics of adsorption on carbon from solution. J. Sanit. Eng. Div. 89, 31, 1963.

43. LANGMUIR I. The adsorption of gases on plane surfaces of glass, mica and platinum. J. Am. Chem. Soc. 40, 1361, 1918.

44. FREUNDLICH H. Concerning adsorption in solutions. Zeitschrift fur physikalische Chemie 57, 385, 1906.

45. DENIZ F., SAYGIDEGER S.D. Removal of a hazardous azo dye (Basic Red 46) from aqueous solution by princess tree leaf. Desalination 268, 6, 2011.

46. KARIM A.B., MOUNIR B., HACHKAR M., BAKASSE M., YAACOUBI A. Removal of Basic Red 46 dye from aqueous solution by adsorption onto Moroccan clay. J. Hazard. Mater. 168, 304, 2009.

47. KONICKI W., ALEKSANDRZAK M., MIJOWSKA E. Equilibrium, kinetic and thermodynamic studies on adsorption of cationic dyes from aqueous solutions using graphene oxide. Chem. Eng. Res. Des. 123, 35, 2017.

48. DUC D.S., VAN NOI N., TRUNG D.Q., QUYEN V.T., NINH V.T. Adsorption of Basic Red 46 onto activated carbon. Res. J. Chem. Environ. 16 (4), 169, 2012.

49. QU S., HUANG F., YU S., CHEN G., KONG J. Magnetic removal of dyes from aqueous solution using multi-walled carbon nanotubes filled with $\mathrm{Fe}_{2} \mathrm{O}_{3}$ particles. J. Hazard. Mater. 160, 643, 2008.

50. KARAGOZ S., TAY T., UCAR S., ERDEM M. Activated carbons from waste biomass by sulfuric acid activation and their use on methylene blue adsorption. Bioresource Technol. 99, 6214, 2008.

51. CHATTERJEE S., WOO S.H. The removal of nitrate from aqueous solutions by chitosan hydrogel beads. J. Hazard. Mater. 164, 1012, 2009.

52. CRINI G., BADOT P.-M. Sorption processes and pollution. Conventional and non-conventional sorbents for pollutant removal from wastewaters, Presses universitaires de Franche-Comté, France, 2010. 
